\title{
PENGEMBANGAN DIRI SEBAGAI FASILITATOR BELAJAR PADA PROGRAM EDUCATION DI SENTUL BOGOR
}

\author{
Widiastuti $^{1}$, Yubali Ani ${ }^{2}$, Ashiong Parhehean Munthe ${ }^{3}$ \\ ${ }^{123}$ Universitas Pelita Harapan
}

Widiastuti.tc@uph.edu, yubali.ani@uph.edu, ashiong.munthe@uph.edu

\begin{abstract}
Abstrak
Kegiatan ini merupakan keberlanjutan dari kerjasama yang dimulai dari tahun akademik 2018-2019 term 1 antara PGSD-FIP Universitas Pelita Harapan dengan Yayasan Emmanuel. Kegiatan yang dilakukan antara lain; pelatihan ini dikhususkan bagi fasilitator belajar agar mampu mengajar secara kreatif dan mempraktikkan kemampuan mengajarnya di lokasi komunitas belajar mereka. Tujuan dari kegiatan pelatihan ini adalah: 1) mengembangkan diri siswa SMA sebagai fasilitator belajar; 2) memimpin para pebelajar yang belajar; 3) mampu memecahkan masalah (problem solver) baik bagi diri sendiri maupun lingkungan; 4) menjadi pembelajar yang kreatif; 5) unggul dalam prestasi belajar; 6) praktik langsung di komunitas belajar yang mereka pimpin. Pelaksanaan kegiatan berupa pelatihan, antara lain: 1) pemberian materi; 2) sesi tanya jawab; 3) merancang rencana pembelajaran, membuat alat peraga, dan menyusun penilaian dari pembelajaran yang dilakukan; 4) permainan di dalam kelompok dengan mentor; dan 5) praktik mengajar langsung secara individu sesuai dengan rencana pelaksanaan pembelajaran yang mereka susun. Kegiatan berlangsung pada peroide bulan Juli-Desember 2018, setiap sabtu 2 kali dalam sebulan. Kegiatan pelatihan yang diberikan membantu siswa memiliki pengetahuan di bidang mengajar, seperti merencanakan sebuah pembelajaran, membuat alat peraga, membuat penilaian sederhana, dan melaksanakan pembelajaran.
\end{abstract}

Kata kunci: pengembangan, fasilitator, problem solver, komunitas belajar.

\section{PENDAHULUAN}

Kegiatan pengembangan diri sebagai fasilitator belajar pada program Edunation di Sentul Bogor ini merupakan kegiatan lanjutan dari kerjasama yang dimulai tahun akademik 2018-2019 term 1 antara PGSD-FIP Universitas Pelita Harapan dengan Yayasan Emmanuel. Program ini merupakan program pelatihan siswa SMA kelas XI-XII untuk menjadi fasilitator belajar bagi anak-anak disekitar lingkungan rumah mereka. Para siswa SMA ini merupakan siswa yang mendapatkan program beasiswa dari Yayasan Emamnuel. Kemudian sebagai kompensasi dari beasiswa tersebut para siswa SMA tersebut harus menolong anak-anak di sekitar rumah mereka dalam proses belajar. Rata-rata anak-anak yang dibantu belajar oleh siswa SMA ini adalah anak-anak yang masih duduk dibangku TKSMP. Anak-anak tersebut biasa disebut sebagai anak-anak partisipan atau disingkat PP.

Pengembangan diri adalah suatu upaya untuk mengembangkan potensi diri sendiri (Hasibuan, 2014). Lebih lanjut Hasibuan mengemukakan bahwa pengembangan diri berkaitan dengan usaha seseorang untuk perbaikan diri, sedangkan perbaikan diri diawali dengan pengenalan

$$
\text { Pendidikan }
$$


akan diri sendiri. Menurut Supriadi (2016) untuk mengembangkan potensi diri perlu mengetahui kekurangan dan kelebihan diri sehingga apa yang akan dilakukan dapat bermanfaat di dalam hidup. Sedangkan menurut Hulukati (2013) pengembangan diri merupakan upaya membantu perkembangan seseorang agar mereka dapat berkembang sesuai potensi masing-masing melalui pemberian kesempatan seseorang tersebut untuk mengembangkan dan mengekspresikan diri dengan kelebihan, minat, kondisi, dan perkembangan. Dengan demikian, pengembangan diri dalam kegiatan ini mencakup pengenalan akan diri sendiri yaitu kelebihan dan kelemahan sehingga mereka dapat mengembangkan potensi diri mereka masingmasing melalui kesempatan kegiatan pelatihan dan workshop ini.

Kemudian yang dimaskud dengan fasilitator adalah kemampuan seseorang baik secara perorangan maupun kelompok yang membantu sekelompok orang lain dalam mencapai tujuan tertentu (Kadir,dkk, 2006 dalam Agung, 2017). Sedangkan belajar adalah proses perubahan perilaku baru secara keseluruhan sebagai hasil dari pengalaman individu itu sendiri dalam berinteraksi dengan lingkungannya (Mohmmad Surya, 1997 dalam Kosasih, 2016). Kemudian peran fasilitator belajar sebagaimana dikemukakan oleh Roestiyah (2001) dalam Warisdino, Sarma, gani, dan Susanto (2013) adalah sebagai pelatih, pemandu, desainer lingkungan belajar, model dan mentor, dan evaluator. Dengan demikian yang dimaksud dengan kegiatan pengembangan diri sebagai fasilitator belajar disini adalah kegiatan di mana mempersiapkan para siswa SMA dalam mengembangkan potensi yang ada dalam dirinya yaitu dengan mengenali diri sendiri sehingga mampu mempersiapkan dirinya sebagai fasilitator belajar yaitu dengan membantu anak-anak partisipan dilingkungan sekitar mereka dalam mencapai tujuan belajar sehingga terjadi perubahan perilaku belajar dalam diri anak-anak partisipan. Fasilitator belajar juga diharapkan dapat menjalankan perannya sebagai pelatih, pemandu, desainer lingkungan belajar, model, dan evaluator bagi para anak-anak partisipannya.

Pada term 1 materi pengembangan diri yang diajarkan antara lain tentang bagaimana siswa tersebut mengenali diri sendiri dengan baik dan beberapa materi tentang fasilitator belajar. Keberhasilan pelaksanaan kegiatan di term 1 terlihat dari komitmen para siswa sebagai peserta dalam mengikuti kegiatan secara keseluruhan yang disesuaikan dengan kondisi keadaan mereka. Para fasilitator belajar mengikuti pelatihan dengan antusias dan menerapkan apa yang dipelajari dari kegiatan ini pada komunitas belajar di lingkungan tempat tinggal mereka dengan baik.

Berdasarkan hasil evaluasi pada term 1 , para siswa mulai percaya diri dan berani tampil di depan orang banyak walaupun masih ada beberapa siswa yang terlihat kurang percaya diri dan takut untuk tampil di depan banyak orang. Oleh karena itu, pada kegiatan pengembangan diri sebagai fasilitator belajar di term 2 ini lebih mengacu kepada permasalahan kemampuan mengajar secara kreatif dan mempraktikkan kemampuan mengajarnya di lokasi komunitas belajar mereka.

Adapun tujuan dari kegiatan ini adalah sebagai berikut: 1) Mengembangkan diri siswa SMA sebagai fasilitator belajar. Para siswa fasilitator belajar mengembangkan kemampuan yang mereka miliki seperti kemampuan memimpin (leadership); 2) Memimpin para pebelajar yang belajar. Para siswa fasilitator belajar menerapkan prosedur kelas saat kegiatan belajar mengajar berlangsung dan mengenal karakter pebelajar di komunitas belajar mereka; 3) Menjadi pemecah masalah (problem solver) baik bagi diri sendiri maupun lingkungan. Para siswa memberikan solusi terhadap permasalahan di komunitas belajar mereka; 4) Menjadi pembelajar yang kreatif. Para siswa menggunakan alat dan bahan yang ada di sekitar komunitas belajar mereka; 5) Unggul dalam prestasi belajar. Para siswa juga menjaga prestasi belajar mereka, sehingga mereka dapat memberi dampak yang baik bagi komunitas belajar mereka; 6) Praktik langsung kepada komunitas belajar yang mereka ajar. Para siswa fasilitator belajar mempraktikkan langsung pembelajaran yang sudah mereka siapkan dengan baik.

Melihat dari tujuan kegiatan yang sudah dipaparkan di atas, maka rencana penanganan masalah yang akan dilakukan adalah dengan memberikan pelatihan-pelatihan berupa workshop yang dilakukan dua minggu sekali setiap hari Sabtu pada periode bulan Juli-Desember 2018. Adapun metode penyelesaian masalahnya adalah dengan

$$
\text { Pendidikan }
$$


memberikan materi-materi pelatihan yang berhubungan dengan permasalah yang ada yaitu kemampuan mengajar secara kreatif dan mempraktikkan kemampuan mengajar. Materimateri tersebut meliputi: cara merancang pembelajaran, merancang penilaian, manner sebagai fasilitator belajar (pria \& wanita), mengajar bahasa Inggris, membuat alat peraga pembelajaran, praktik mengajar, dan lomba microteaching para fasilitator belajar.

Materi-materi tersebut dirancang sesuai dengan kompetensi-kompetensi yang harus dimiliki seorang guru. Guru sangat berkaitan dengan fasilitator belajar, karena salah satu peran guru yang cukup penting adalah sebagai fasilitator belajar. Menurut Suyatno dan Jihad (2013) guru memiliki peran sebagai fasilitator yaitu menyediakan kemudahankemudahan bagi siswa dalam proses belajar mengajar. Oleh karena itu, materi-materi yang diberikan dalam kegiatan ini disesuaikan dengan kompetensi-kompetensi guru. Seorang guru dalam hal ini fasilitator belajar harus memiliki empat kompetensi yaitu kompetensi pedagogik, kompetensi kepribadian, kompetensi sosial, dan kompetensi profesional. Beberapa kompetensi pedagogik harus dikuasai guru adalah kemampuan merancang pembelajaran dan kemampuan merancang penilaian. Menurut Philip Commbs yang dikutip oleh Rahayu (2013) perencanaan pembelajaran adalah suatu penerapan rasional dari analisis sistematis proses perkembangan pendidikan dengan tujuan agar pendidikan lebih efektif dan efisien sesuai dengan kebutuhan dan tujuan para murid dan masyarakatnya. Secara spesifik perencanaan pembelajaran ini mengajarkan para siswa SMA membuat Rencana Pelaksanaan Pembelajarn (RPP) yang terdiri dari tujuan pembelajaran, isi (materi pembelajaran), kegiatan pembelajaran, media dan sumber belajar, dan evaluasi.

Kemampuan evaluasi sendiri akan dibahas lebih dalam dalam satu sesi. Menurut Suyanto dan Jihad (2013) penilaian memberikan penekanan pada usaha yang dilakukan oleh guru dan siswa untuk memperoleh informasi yang berkaitan dengan pembelajaran yang mereka lakukan. Informasi tersebut kemudian dijadikan umpan balik untuk melakukan perubahan aktivitas belajar mengajar yang lebih baik dari sebelumnya. Tujuan evaluasi adalah diagnostik yaitu untuk mengidentifikasi kinerja siswa, formatif yaitu membantu belajar siswa, sumatif yaitu meninjau, mentransfer, dan sertifikasi, dan evaluatif yaitu melihat bagaimana kinerja guru atau institusi (Weeden, Winter, dan Broadfoot, 2002 dalam Suyanto dan Jihad, 2013).

Salah satu kompetensi kepribadian yang sampaikan ke peserta pelatihan ini adalah manner sebagai fasilitator belajar. Menurut Daryanto dan Tasrial (2015) kompetensi kepribadian terkait dengan guru sebagai teladan, beberapa aspek kompetensi ini misalnya: dewasa, stabil, arif dan bijaksana, berwibawa, mantab, berakhlak mulia, menjadi teladan bagi perserta didik dan masyarakat, mengevaluasi kinerja sendiri, dan mengembangkan diri secara berkelanjutan. Selain itu dalam pelatihan ini juga ditambahkan tentang bagaimana merawat diri, cara berpakaian yang tepat saat mengajar, dan etika sebagai seorang guru.

Kompetensi berikutnya adalah kompetensi sosial. Menurut Suyanto dan Jihad (2013) kompetensi sosial merupakan kemampuan yang harus dimiliki guru untuk berkomunikasi dan bergaul secara efektif dengan siswa, sesama pendidik, tenaga kependidikan, orang tua/wali siswa, dan masyarakat sekitar. Untuk melatih peserta pelatihan dalam mengembangkan kemampuan sosialnya ini maka dalam setiap pelatihan peserta pelatihan akan melakukan kerja kelompok untuk melatih kemampuan berkomunikasi, bergaul, dan bekerjasama dengan sesama peserta pelatihan.

Terakhir untuk kompetensi profesional juga menjadi materi yang dibagikan didalam kegiatan ini. Kompetensi profesional merupakan penguasaan materi pembelajaran secara luas dan mendalam yang harus dikuasai guru mencakup penguasaan materi kurikulum mata pelajaran di sekolah dan subtansi keilmuan yang menaungi materi serta penguasaan terhadap struktur dan metodologi keilmuan (Suyanto dan Jihad, 2013). Dalam pelatihan ini penguasaan materi-materi pembelajaran hanya melatihkan materi bahasa Inggris. Hal ini dikarenakan pada term 1 sudah diberikan materi-materi mata pelajaran lainnya seperti matematika, bahasa Indonesia, IPA, IPS, dan PKKN. Selain itu materi bahasa Inggris menjadi kebutuhan utama para peserta untuk mengembangkan diri kemampuannya dalam berbahasa Inggris.

$$
\text { Pendidikan }
$$


Selain itu kompetensi profesional berikutnya yang diajarkan adalah membuat alat peraga pembelajaran. Alat peraga merupakan media pembelajaran yang memudahkan fasilitator belajar dalam menyampaikan materi pembelajaran pada anak-anak partisipannya. Menurut Briggs yang dikutip oleh Kosasih (2016) media adalah segala alat fisik yang dapat menyajikan pesan serta mendorong siswa untuk belajar. Lebih lanjut Kosasih menjelaskan bahwa media memiliki ciri-ciri sebagai berikut: 1) menarik perhatian dan minat siswa; 2) meletakkan dasar-dasar untuk memahami secara konkret; 3) sederhana, mudah digunakan dan dirawat, dapat dibuat sendiri atau diambil dari lingkungan sekitar. Melalui materi ini peserta pelatihan diajarkan untuk bagaimana membuat media pembelajaran sendiri sesuai dengan materi dari pembelajaran yang sudah dirancangkan dalam RPP dengan bahan-bahan yang sederhana dan mudah didapatkan.

Ketika seluruh kompetensi sudah diberikan dalam pelatihan ini, maka sebagai puncak dari pelatihan ini adalah praktik mengajar. Praktik mengajar ini merupakan rangkaian dari semua yang sudah dipelajari. Para peserta akan mempraktikkan mengajar dari materi yang sudah dipersiapkan dalam RPP yang dibuat dengan menggunakan alat peraga atau media pembelajaran dan menyampaikan jenis penilaian yang sudah mereka buat. Kemudian dari praktek mengajar ini para peserta akan mendapatkan evaluasi dari para pengajar dan mentor yang kemudian diperbaiki dan mereka dapat mengikuti lomba microteching. Lomba ini bertujuan untuk melihat kemampuan mengajar para peserta pelatihan secara maksimal. Selain itu juga memotivasi para peserta pelatihan untuk menampilkan kreativitas mereka dalam mengajar. Dengan demikian diharapkan para peserta pelatihan dapat mengembangkan diri dalam menerapkannya ke komunitas belajar mengajar dilingkungan sekitar mereka.

\section{METODE}

Pelaksanaan kegiatan berupa pelatihan, antara lain: 1) pemberian materi; sesi tanya jawab; 2) merancang rencana pembelajaran, membuat alat peraga, dan menyusun penilaian dari pembelajaran yang dilakukan; 3) aktivitas di dalam kelompok dengan mentor; 4) dan praktik mengajar langsung secara individu sesuai dengan rencana pelaksanaan pembelajaran yang mereka susun.

Tabel 1. Susunan Topik Kegiatan Pelatihan

\begin{tabular}{|c|c|c|}
\hline Tanggal & Topik & PIC \\
\hline $25 / 08 / 2018$ & Cara merancang pembelajaran & $\begin{array}{c}\text { Dosen } \\
\text { \&Mentor }\end{array}$ \\
\hline 08/09/2018 & Cara merancang penilaian & $\begin{array}{l}\text { Dosen } \\
\& \text { Mentor }\end{array}$ \\
\hline 06/10/2018 & Manner (Pria dan wanita) & $\begin{array}{l}\text { Dosen } \\
\text { \&Mentor }\end{array}$ \\
\hline $20 / 10 / 2018$ & Cara mengajar Bahasa Inggris & $\begin{array}{l}\text { Dosen } \\
\& \text { Mentor }\end{array}$ \\
\hline 03/11/2018 & $\begin{array}{l}\text { Cara membuat alat peraga } \\
\text { pembelajaran }\end{array}$ & $\begin{array}{l}\text { Dosen } \\
\text { \&Mentor }\end{array}$ \\
\hline $17 / 11 / 2018$ & Praktik mengajar & $\begin{array}{l}\text { Dosen } \\
\text { \&Mentor }\end{array}$ \\
\hline 08/11/2018 & $\begin{array}{l}\text { Lomba mikroteaching para } \\
\text { fasilitator belajar }\end{array}$ & $\begin{array}{l}\text { Dosen } \\
\& \text { Mentor }\end{array}$ \\
\hline
\end{tabular}

Pelaksanaan acara setiap Sabtu pkl. 10.00-15.00 di Yayasan Emmanuel, Sentul Bogor:

10.00-12.00 Pengajar menjelaskan materi

12.00-13.00 lunch (disediakan)

13.00-14.45 Aktivitas yang sesuai dengan topik

14.45-15.00 Kesimpulan dan penutup

Adapun tanggung jawab dari peserta pelatihan selama kegiatan berlangsung antara lain: 1) menyimak materi yang dibawakan oleh dosen pengajar; 2) membuat mind mapping mengenai materi yang sudah diajarkan dengan kreativitas mereka sendiri dengan mentor; 3) latihan bagaimana menjadi seorang guru; 4) mengerjakan tugas yang diberikan di dalam kelompok bersama dengan mentor; 5) mempraktikkan dan mempresentasikan apa yang sudah mereka buat sesuai topik.

\section{HASIL DAN PEMBAHASAN}

Kegiatan pelatihan dan workshop ini telah terlaksana dengan baik dan sesuai dengan rencana kegiatan yang telah dibuat. Para pengajar, mentor dan peserta (siswa SMA) mengikuti kegiatan dengan baik. Adapun hasil kegiatan pelatihan dan workshop pengembangan diri sebagai fasilitator belajar pada program Edunation ini adalah sebagai berikut: 
Berdasarkan hasil observasi yang dilakukan selama proses pelatihan berlangsung didapati bahwa hampir seluruh fasilitator belajar menunjukkan adanya pengembangan diri dalam diri fasilitator belajar. Hal ini terlihat dari keberanian mereka dalam mengemukakan pendapat, percaya diri saat praktik mengajar maupun saat lomba microteaching, kemampuan memimpin saat aktivitas-aktivitas dikelompok, kreatif dalam membuat alat peraga dan disiplin dalam mengikuti pelatihan dan workshop. Sejauh ini berdasarkan hasil observasi disiplin yang ditunjukkan para peserta seperti yang dikemukakan oleh Sutrisna (1993) dalam Miranda (2009) perilaku disiplin ini meliputi: kehadiran tepat waktu, kerjasama yang baik dengan rekan kerja dalam hal ini anggota kelompok, sopan santun dengan anggota kelompok, dan konsisten dalam bekerja.

Hal ini juga didukung dari hasil angket yang dibagikan para fasilitator belajar pada akhir pelatihan dan workshop. Sebagian besar dari peserta pelatihan mengungkapkan bahwa pelatihan ini sangat penting bagi mereka karena mereka mendapatkan banyak materi yang dapat membawa perubahan dalam diri mereka. Mereka belajar untuk lebih percaya diri dan berani berbicara baik di kelas besar maupun pada saat di dalam kelompok. Mereka juga belajar bertanggung jawab dan sabar.

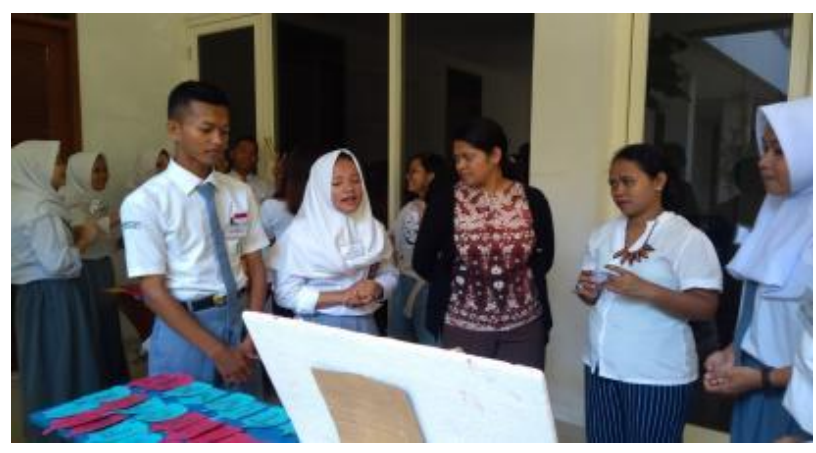

Gambar 1. Peserta pelatihan tampil percaya diri dalam mempresentasikan hasil kerja kelompok.

Pengembangan diri dalam diri peserta ini sangat penting bagi mereka dalam menjalankan peran mereka sebagai fasilitator belajar. Hal ini akan memupuk kompetensi kepribadian mereka sebagai seorang fasilitator belajar. Keberanian mengemukakan pendapat, percaya diri, memiliki jiwa memimpin dan disiplin menjadi modal utama mereka dalam mereka menjalankan sebagai fasilitator belajar di komunitas sekitar mereka. Mereka tidak perlu lagi merasa malu dan tidak berani untuk mengajar anak-anak partisipan mereka, mereka mampu memimpin anak-anak partisipan dalam belajar, mereka juga dapat mendisiplin anakanak partisipan mereka. Materi manner yang diberikan mengembangkan diri para fasilitator belajar dalam bagaimana bersikap terhadap anakanak partisipan, bagaimana berpakaian yang rapi saat mengajar, dan bagaimana merawat diri sebagai seorang fasilitator belajar. Sekalipun hal ini dianggap sederhana namun ini cukup penting bagi para peserta dalam menjalankan perannya sebagai seorang fasilitator belajar.

Selain dari kompetensi kepribadian para peserta yang berkembang, kompetensi sosial para fasilitator belajar juga mengalami perkembangan. Pada awal pelatihan dan wrokshop berlangsung siswa cenderung diam, malu, dan sulit untuk berinteraksi dan bekerjasama dengan sesama peserta lainnya. Perlu diketahui bahwa peserta pelatihan terdiri dari beberapa sekolah SMA dan SMK yang berbeda. Namun selama pelatihan ini berlangsung dari hasil observasi maka didapati bahwa para peserta mampu beradaptasi dan membaur dengan anggota lainnya. Hal ini terlihat pada saat mereka bekerja sama di dalam kelompok. Pembagian kelompok memang dilakukan secara heterogen, di setiap kelompok terdiri dari peserta yang berbeda sekolahnya sehingga para perserta belajar bekerjasama dengan peserta lainnya. Hasil observasi berikutnya adalah mereka mampu berkomunikasi dengan baik satu sama lainnya, bahkan mereka mulai berani bercanda tawa dengan yang lainnya. Kemudian dari hasil observasi juga didapati bahwa mereka mampu bekerjasama diantara para perserta lainnya dalam melakukan aktivitas yang disediakan para mentor dan pengajar.

Hasil observasi tersebut didukung juga dengan hasil angket yang telah dibagikan oleh para peserta pelatihan. Sebagian besar dari mereka mengemukakan bahwa melalui kerja kelompok ini mereka mengalami perubahan dalam hal berkomunikasi. Mereka berani bertanya jawab atau sekedar mengemukakan pendapat. Selain itu mereka juga mengungkapkan bahwa mereka belajar untuk

$$
\text { Pendidikan }
$$


saling menghargai dan menghormati orang lain yang berbeda agama. Mereka juga belajar tentang bagaimana bersikap toleransi dan peduli dengan sesama.

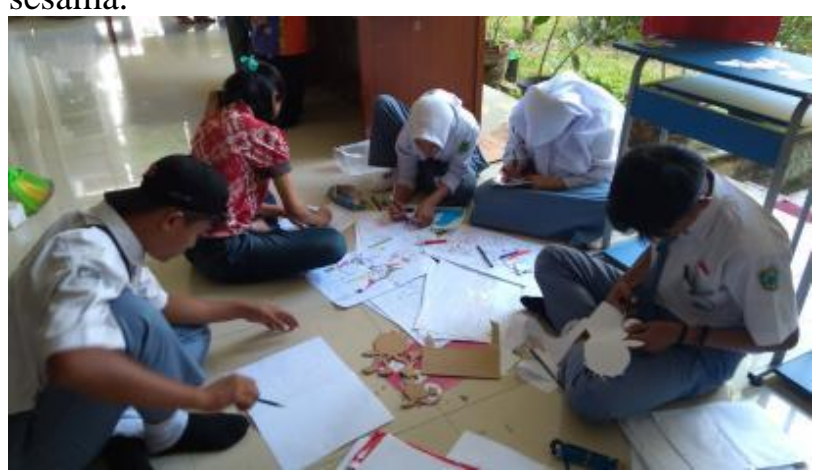

Gambar 2. Aktivitas di dalam kelompok 1

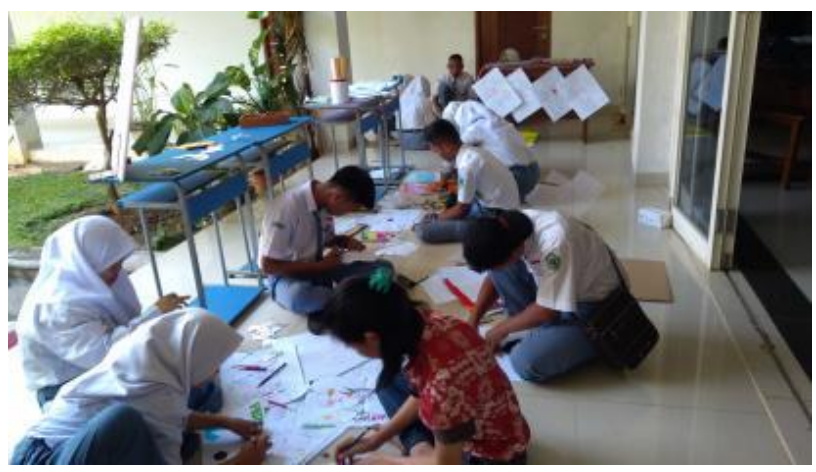

Gambar 3. Aktivitas di dalam kelompok 2

Kompetensi sosial ini sangat menolong bagi para fasilitator belajar dalam mereka membangun kerjasama antar sesama faslitator belajar. Kerjasama sangat diperlukan untuk membagun daya kreativitas mereka dalam mengajar melalui diskusi dan kerjasama yang dilakukan didalam kelompok. Selain itu juga menolong para fasilitator belajar untuk membangun komunikasi dengan sesama peserta dan juga melatih komunikasi dengan baik pada saat mereka mengajar di komunitas belajar setitar mereka. Melalui kerja kelompok para fasilitator juga belajar untuk memecahkan masalah. Hal ini sangat penting dalam kehidupan mereka. Keterampilan memecahkan masalah sangat menolong mereka untuk mengatasi permasalahan-permasalahan yang muncul di dalam komunitas belajar di lingkungan mereka.

Pengalaman saling menghargai dan menghormati antar anggota kelompok juga menolong mereka dalam menghargai dan menghormati anak-anak partisipan mereka.
Kompetensi sosial ini sangat luas dampaknya bukan hanya bagi fasilitator belajar dengan kelompoknya, atau dengan komunitas belajar disekitar rumah mereka, namun juga berdampak pada masyarakat luas disekitar mereka.

Pengembangan diri para fasilitator belajar berupa kompetensi kepribadian dan kompetensi sosial memang terasa manfaatnya bagi mereka sendiri secara pribadi. Secara sadar mereka telah mempersiapkan diri menjadi fasilitator belajar yang handal. Selain dari dua kompetensi tersebut maka kompetensi yang langsung berhubungan dengan tugas mengajar mereka adalah kompetensi pedagogik dan kompetensi professional.

Berdasarkan hasil observasi didapati bahwa kompetensi pedagogik para fasilitator belajar mengalami perkembangan yang baik. Para fasilitator belajar menunjukkan kemampuan mereka dalam membuat perencanaan pembelajaran. Sebagian besar mereka telah membuat rencana pembelajaran secara sistematis sesuai dengan materi yang akan mereka ajarkan. Rencana pembelajaran yang mereka buat antara lain memaparkan tentang tujuan pembelajaran, kegiatan pendahuluan, kegiatan inti, dan kegiatan penutup. Selain itu juga mereka menunjukkan juga kemampuan mereka membuat penilaian berdasarkan tujuan pembelajaran yang telah mereka buat.

Sedangkan hasil angket mengungkapkan bahwa mereka menjadi tentang pentingnya merancang pembelajaran sebelum mereka mengajar. Mereka juga mengungkapkan bahwa mereka menjadi tahu bagaimana membuat rencana pembelajaran, menetapkan tujuan pembelajaran, kegiatan pendahuluan, kegiatan inti, dan kegiatan penilaian.

Kemampuan para fasilitator belajar dalam mengajar juga terlihat saat praktek mengajar dan juga lomba microteaching. Secara keseluruhan para fasilitator belajar sudah cukup berani dan percaya diri dalam praktik mengajar maupun pada saat lomba microteaching. Hanya ada satu dua fasilitator belajar yang masih tampak gugup saat praktek mengajar. Mereka juga dalam

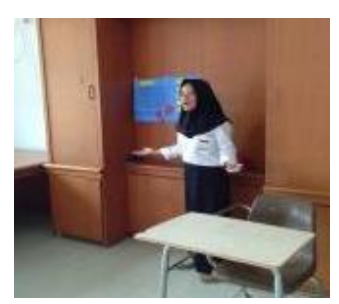
tampil kreatif mengajar. 
Gambar 4. Praktek mengajar

Kompetensi pedagogik ini sangat penting bagi para fasilitator belajar. Kompetensi pedagogik ini memberikan pengalaman mengajar yang sesuai dengan rencana pembelajaran yang telah mereka rencanakan. Hal ini mendorong para fasilitator belajar dalam menerapkan keterampilan mengajar di komunitas belajar disekitar mereka.

Kompetensi yang terakhir adalah kompetensi profesional yaitu kemampuan para fasilitator belajar dalam menguasai materi pembelajaran. Pada pelatihan ini para peserta diajarkan tentang materi bahasa Inggris. Hal ini merupakan kebutuhan dari para fasilitator belajar berdasarkan angket yang diberikan. Mereka mengungkapkan pentingnya diajarkan materi bahasa Inggris. Oleh karena itu pada pelatihan ini materi ini diajarkan. Materi mata pelajaran yang lain telah diajarkan pada term 1.Selain itu untuk meningkatkan kompetensi profesional lainnya adalah diajarkan membuat media pembelajaran berupa alat peraga.

Berdasarkan hasil observasi, para fasilitator belajar membuat alat peraga pembelajaran dengan kreatif. Mereka membuat alat peraga dari bahanbahan yang mudah mereka dapatkan disekitar mereka dan disesuaikan dengan materi yang mereka hendak ajarkan atau yang ada di dalam rencana pembelajaran.

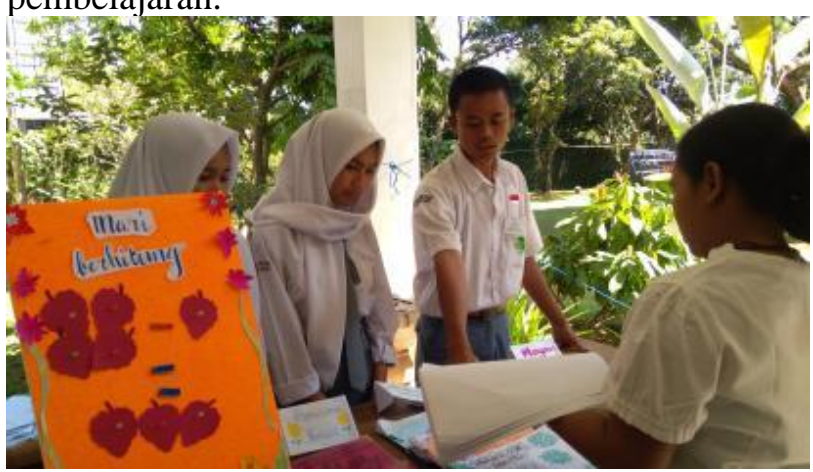

Gambar 5. Alat peraga Matematika
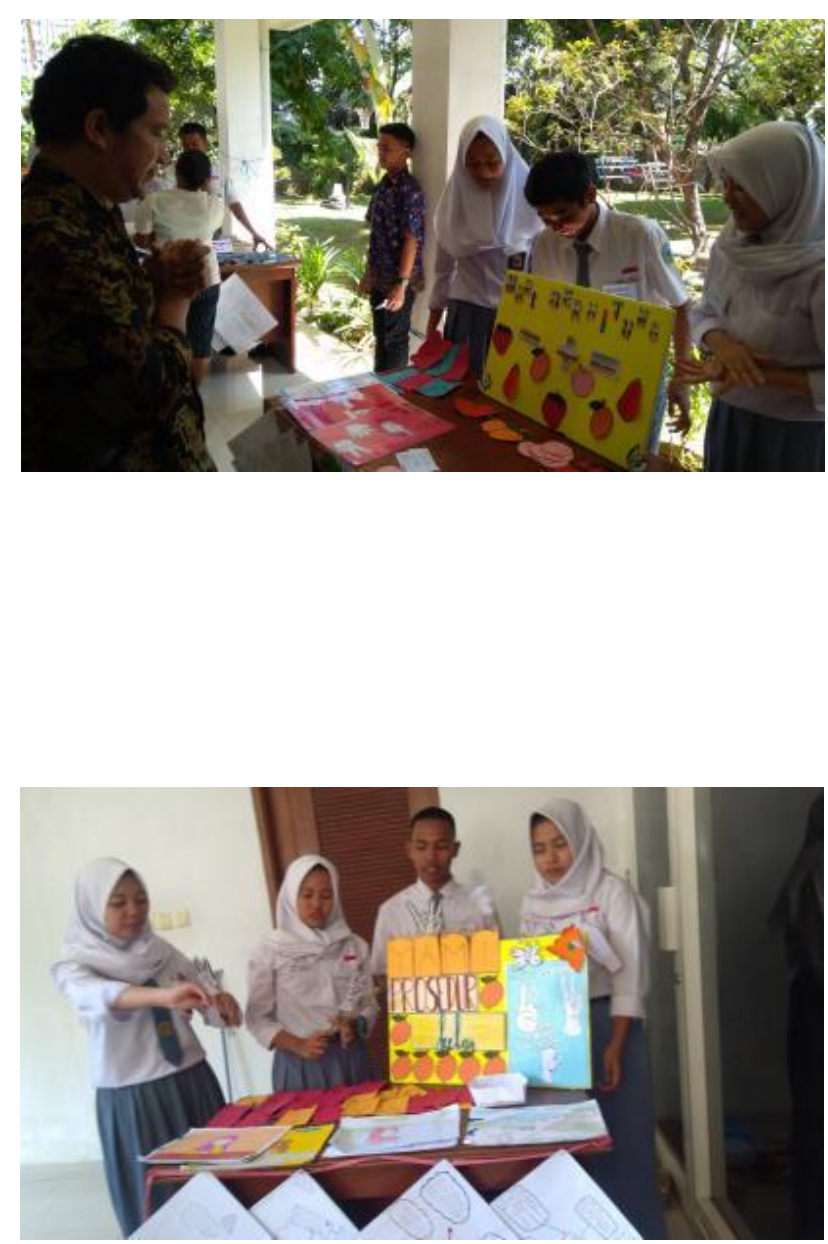

Gambar 6. Alat peraga Prosedur

Gambar 7. Contoh alat peraga lainnya

Ke empat kompetensi fasilitator belajar tersebut sangat bermanfaat bagi para peserta pelatihan dalam membekali mereka menjadi seorang fasilitator belajar bagi anak-anak partisipan mereka. Kemampuan yang mereka miliki sudah hampir menyerupai seorang guru sesungguhnya. Namun dengan adanya pelatihan dan workshop ini diharapkan juga dapat mendorong para peserta untuk tetap berprestasi di dalam belajar mereka sebagai siswa SMA. Berdasarkan data dari angket yang mereka isi mereka menyadari bahwa perubahan diri mereka berdampak pada peran mereka sebagai siswa di sekolah tempat mereka belajar. Mereka mengungkapkan bahwa mereka menjadi pribadi yang percaya diri, disiplin mematuhi peraturan-

$$
\text { Pendidikan }
$$


peraturan di sekolah, mampu mengatur waktu belajar mereka, ada satu dari mereka yang menjadi ketua Osis, aktif dalam berorganisasi di sekolah, rajin piket kelas dan memiliki cita-cita.

Sebagian dari para peserta, pada awal pelatihan tidak memiliki cita-cita setelah mereka lulus dari sekolah. Namun setelah mengikuti pelatihan dan workshop ini mereka mulai menanamkan dalam diri mereka untuk berani memiliki cita-cita. Ada beberapa dari mereka yang pada akhirnya memiliki cita-cita menjadi guru.

Tujuan akhir dari pelatihan dan workshop ini adalah membekali para peserta untuk menerapkan semua materi pelatihan ke dalam praktek-praktek mengajar mereka di komunitas belajar mereka di lingkungan sekitar mereka. Hampir seluruh peserta sudah memiliki anak-anak partisipan untuk dibantu dalam hal belajar. Ada yang memiliki satu atau dua anak partisipan, ada yang memiliki lima sampai sepuluh partisipan dan ada yang sampai memiliki 30 anak partisipan. Sebagian besar dari mereka sudah menerapkan materi-materi yang diajarkan dalam pelatihan ini ke dalam praktek mengajar mereka. Hal ini dapat dilihat dari hasil observasi di komunitas belajar mereka.

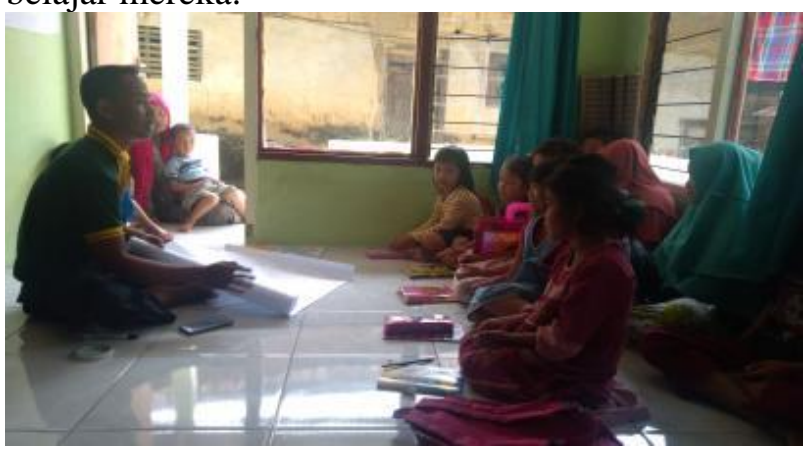

Gambar 8. Mengajar anak-anak partisipan

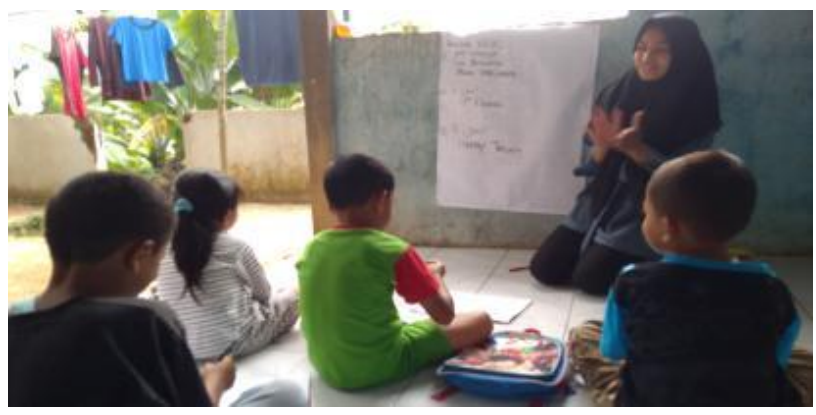

Gambar 9. Mengajar anak-anak partisipan
Adapun respon dari masyarakat sekitar tentang program edunation yang dijalankan oleh para fasilitator belajar ini sangat baik. Berdasarkan sharing dari para fasilitator belajar masyarakat senang dengan adanya komunitas belajar ini dilingkungan mereka. Hal ini dikarenakan lingkungan berada di daerah yang cukup jauh dari sekolah. Masyarakat menyambut dengan baik dan mendukung program Edunation ini. Selain itu prestasi anak-anak partisipan juga menunjukkan perkembangan yang baik yaitu dari yang tidak bisa membaca dan berhitung mereka menjadi lancar membaca dan berhitung. Ada juga yang sebelum mengikuti komunitas belajar di program Edunation ini malas belajar menjadi rajin belajar bahkan ada dari anak-anak partisipan menjadi memiliki kebiasaan belajar secara mandiri. Orang tua tidak perlu mendorong-dorong anak-anaknya untuk belajar. Ada juga yang awalnya tidak pernah juara satu dikelasnya menjadi juara satu dikelasnya. Dengan demikian program Edunation melalui komunitas belajar yang dilakukan oleh para fasilitator belajar dilingkungan mereka memberikan dampak yang sangat baik bagi masyarakat luas. Sekalipun mereka masih duduk dibangku SMA namun mereka sudah mampu memberi dampak yang besar bagi masyakarakat sekitar mereka.

\section{KESIMPULAN}

Pelaksanaan kegiatan pelatihan dan workshop pengembangan diri sebagai fasilitator belajar pada program Edunation di Sentul Bogor ini sangat bermanfaat bagi para fasilitator belajar itu sendiri, maupun bagi masyarakat luas. Para fasilitator belajar memperoleh banyak manfaat yaitu mengembangkan diri dalam berbagai kompetensi, baik itu kompetensi kepribadian dan sosial yang sangat berdampak langsung dengan pengembangan diri mereka sendiri, maupun kompetensi pedagogik dan kompetensi profesional yang berdampak pada cara mereka mengajar di komunitas belajar lingkungan sekitar mereka. Tidak berhenti sampai di sana, dampak dari komunitas belajar itu pun sampai kepada masyarakat luas. Melihat dampak dari kegiatan ini sangat besar, maka untuk ke depannya kegiatan ini dapat dilaksanakan secara kontinyu dan berkelanjutan dengan peserta yang berbeda. 


\section{UCAPAN TERIMAKASIH}

Terima kasih untuk Yayasan Emmanuel yang telah memberikan kesempatan atas terlaksananya kegiatan ini. Terima kasih juga kami ucapkan kepada program studi Pendidikan Guru Sekolah Dasar Universitas Pelita Harapan yang telah memberikan kesempatan bagi para dosen untuk melaksanakan program Pengabdian ke Masyarakat ini (PM-051-M/FIP/VIII/2018).

\section{REFERENSI}

Agung I. (2017). Peran Fasilitator Guru Dalam Penguatan Pendidikan Karakter (PPK). Jurnal Perspektif Ilmu Pendidikan, 31 (2): 106-119. Daryanto dan Tasrial. (2015). Pengembangan Karir Profesi Guru. Yogyakarta: Penerbit Gava Media.

Eko Warisdiono E., Sarma M., Gani D.S., Susanto D. (2013). Kompetensi Fasilitator Pelatihan Pusat Pengembangan dan Pemberdayaan Pendidik dan Tenaga Kependidikan Pertanian (P4TK Pertanian) Kementrian Pendidikan dan Kebudayaan. Jurnal Penyuluhan, 9 (2): 109-119.

Hasibuan M. (2014). Pengembangan Diri Menjadi Agen Pembesar Sejati. Jurnal Anaytica Islamica, 3 (2): 296-313.
Hulukati W. (2013). Perangkat Pengembangan Diri Untuk Meningkatkan Kompetensi Guru dan Pengembangan Kepribadian Siswa SMA. Jurnal Ilmu Pendidikan, 19 (2): 136141.

Kosasih. (2016). Strategi Belajar dan Pembelajaran: Imlementasi Kurikulum 2013. Bandung: Penerbit Yrama Widya.

Miranda D. (2009). Pengembangan Diri Melalui Pemberdayaan Diri. Jurnal Visi Ilmu Pendidikan, 1 (1): 78-88.

Rahayu T. (2013). Strategi Pembelajaran Pendidikan Jasmani: Implementasi pada Pembelajaran Pendidikan Jasmani Olahraga dan Kesehatan. Bandung: Penerbit Alfabeta.

Supriadi H. (2016). Peranan Pendidikan Dalam Pengembangan Diri Terhadap Tantangan Era Globalisasi. Jurnal Ilmiah Prodi Manajemen Universitas Pamulang, 3 (2): 92-119.

Suyanto dan Jihad A. (2013). Menjadi Guru Profesional: Strategi Meningkatkan Kualifikasi dan Kualitas Guru di Era Global. Jakarta: Penerbit Erlangga. 